\title{
FUNCTIONAL INCOME DISTRIBUTION AND GROWTH IN SOUTH KOREA: A POST KEYNESIAN ECONOMETRIC ANALYSIS
}

\author{
Ozan Ekin KURT
}

\begin{abstract}
The aim of this article is to analyze the short-term impact of functional income distribution on aggregate demand and its components in South Korea within a post Keynesian framework, in which demand regime of an economy is either wage or profit-led. The article firstly portrays the structural change and the macroeconomic performance of South Korea, and then presents the evolution of the labor income share in the country. The article follows with the presentation of the theoretical model employed for the analysis of the demand regime in the country and offers a survey of the empirical literature of the post Keynesian models of income distribution and growth. Then takes place the econometric analysis and the article proceeds with the evaluation of the results and concludes. The econometric investigation shows that, over the period 1970-2011, the growth regime of the domestic economy is wage-led, while that of the total economy is profit-led. The results are partially in contradiction with those already found in the literature and point that pro-labor growth policies are not viable within the current structure of the South Korean economy in the short run.
\end{abstract}

Keywords: Income Distribution, Demand, Growth, Post Keynesian Economics, South Korea

JEL Classification: E12; E20; E22; E25; E61

\section{GÜNEY KORE'DE FONKSIYYONEL GELİR DAĞILIMI VE BÜYÜME: POSTKEYNEZYEN EKONOMETRIKK BİR ANALİZ}

\section{Özet}

Bu makalenin amacı fonksiyonel gelir dağılımının Güney Korénin toplam talep ve bileşenleri üzerindeki kısa dönem etkisini, ekonomilerin talep rejimlerinin ücret ya da kâr çekişli olduğu postkeynezyen bir çerçeve içerisinde incelemektir. Makale ilk olarak Güney Korénin yapısal değişimini ve makroekonomik performansını tasvir etmektedir ve sonra ülkedeki ücret payının değişimini sunmaktadır. Makale, ülkenin talep rejiminin analizinde kullanilan teorik modelin sunumuyla devam etmekte ve postkeynezyen gelir dağılımı ve büyüme modelleriyle ilgili ampirik bir literatür taraması sunmaktadır. Sonrasında ekonometrik analizi yer alıyor ve makale bulguların değerlendirilmesiyle devam edip sonuçlanıor. Ekonometrik analiz

* $\quad$ Assistant Professor, Yeditepe University Economics Department, İnönü Mah. Kayışdağı Cad. 326A 26 Ağustos Yerleşimi 34755 Ataşehir - İstanbul, TURKEY, ozanekinkurt@gmail.com, ozan.kurt@yeditepe.edu.tr 
1970-2011 dönemi içerisinde yurtiçi ekonominin büyüme rejiminin ücret-çekişli, ekonominin bütünün ise kâr-çekişli olduğunu gösteriyor. Bulgular, literatürdeki daha önceki bulgularla kısmen çelişiyor ve emekten yana büyüme politikalarının kısa vadede Güney Kore ekonomisinin mevcut yapısı içerisinde uygulanabilir olmadığına işaret ediyor.

Anahtar Kelimeler: Fonksiyonel Gelir Dağılımı, Talep, Büyüme, Postkeynezyen İktisat, Güney Kore

JEL Sınıflaması: E12; E20; E22; E25; E61

\section{Introduction}

Since the last economic and financial crisis of 2008-2009, the questions around income distribution and inequality have been raised more loudly than ever. ${ }^{1}$ The studies focusing on personal income and wealth distributions, such as the best seller of Thomas Piketty ${ }^{2}$, has had large media coverage. The hailed capitalist globalization would bring development and equal chances to peoples from different regions of the world, however, its consequences are quite the contrary. The share of labor in total production is in decline all over the world along with relatively lower growth rates and higher unemployment rates since 1980s.

South Korea is no exception of the whole picture. The growth experience and the ever-increasing export orientation of the country were shown as a leading success story among the "Four Asian Tigers". ${ }^{3}$ The country achieved an average growth rate of $8.8 \%$ starting from 1960 until the Asian crisis of 1997 when the economy shrank by almost $6 \%$. However, the average annual growth rates of the post-crisis periods are far from the historical records: 4.6\% between 1998 and 2015, and $3.1 \%$ between 2008 and $2015 .{ }^{4}$ A significant decline share of labor in total income accompanied the relatively lower growth rates in the last four decades. ${ }^{5}$

The crisis of 2008-2009 and the insufficient recovery that followed show the limits of the exportled growth policies. The most striking evidence is the decelerating Chinese growth. This situation brings forward the recipe of rebalancing growth in favor of the domestic market for export-led growth countries, including South Korea. A stronger role for the domestic market implies that an increase of household consumption offsets, at least partially, a decrease in net exports. ${ }^{6}$

$1 \quad$ Foster and Yates (2014) provide a quick example: A simple search of the phrase "income inequality" in the New York Times archive among the articles between 2007 and 2014 results in 4260 entries while it is 2660 for the period 19772007. Foster, J.B., Yates, M.D. (2014). Piketty and the Crisis of Neoclassical Economics, Monthly Review, 66(6): 1-24.

2 Piketty, T. (2014). Capital in the 21st Century, Cambridge (US), Harvard University Press.

3 The other "tigers" are Taiwan, Hong Kong and Singapore.

4 World Bank (2017). World Bank Development Indicators, http://databank.worldbank.org/data/download/WDI_ excel.zip, (Date of Access: 01.03.2017)

5 The decline of the labor income share in South Korea is addressed in detail in the related section.

6 Jetin, B., Kurt, O.E. (2016). Functional income distribution and growth in Thailand: A post Keynesian econometric analysis, Journal of Post Keynesian Economics, 39(3): 334-60. 
This article focuses on the relation between the functional income distribution and demand in South Korea to examine whether pro-labor growth policies are feasible for this country. From a post Keynesian view, an increasing share of labor income must have a higher positive effect on household consumption in order to offset its negative effect on investment and net exports. If this can be achieved, the demand-regime is called wage-led; otherwise it is profit-led. In order to analyze the demand regime in South Korea, we employ the post Keynesian model developed by Jetin and Kurt ${ }^{7}$, which is based on the Bhaduri-Marglin ${ }^{8}$ type of model of Stockhammer, Onaran, and Ederer ${ }^{9}$.

The South Korean economy has already been examined from a post Keynesian view ${ }^{10}$; however, this article brings two novelties to the analysis of the country. The first contribution is the application of the model of Jetin and Kurt ${ }^{11}$, which propose a new treatment of international trade within a post Keynesian model. The export prices are endogenized in a price-maker/taker setting and the exports are dependent on relative export prices in this model. The second contribution is the use of an alternative labor income share series for the analysis of the demand regime.

This article is organized as follows. Next section presents the structural change and the macroeconomic performance of South Korea. The third section focuses on the evolution of the labor income share of the country. The fourth section presents the theoretical approach. The fifth section offers a survey of the empirical literature. The penultimate section describes the estimation procedures of parameters of the theoretical model and presents the econometric investigation and their results. The last section concludes with a general assessment and policy discussions.

\section{South Korea's Structural Change and Macroeconomic Performance}

South Korea was considered to be a low-income country by the World Bank by 1960. The country suffered from high trade deficits that were covered by the U.S. aid. The coup détat in May 1961 by General Park Chung Hee became a turning point in the history of the country. In two decades the country became the top third of all middle-income oil importing countries according to the World Bank's classification. The average annual growth rate of the economy in the period 1960-70 was $8.6 \%$ compared to $5.8 \%$ of the average of the middle-income countries. During the following decade, the macroeconomic performance of the country was even more impressive: 9.5\% compared to $5.6 \%$ of the middle-income countries. The attained high growth rates are due to the breakthrough in industry (17.2\% during 1960-70 and 15.4\% during 1970-80) and manufacturing (17.6\% during $1960-70$ and $16.6 \%$ during 1970-80). ${ }^{12}$

7 Jetin and Kurt, 2016.

8 Bhaduri, A. and Marglin, S. (1990). Unemployment and the real wage: the economic basis for contesting political ideologies, Cambridge Journal of Economics, 14(4): 375-93.

9 Stockhammer, E. et al. (2009). Functional Income Distribution and Aggregate Demand in the Euro-area, Cambridge Journal of Economics, 33(1): 139-59.

10 These studies and their results are addressed at the following sections.

11 Jetin and Kurt, 2016.

12 Hart-Landsberg, M. (1993). The rush to development: Economic change and political struggle in South Korea, New York, Monthly Review, p.26-27. 
The South Korean economy passed through a rapid and vast structural transformation during those two decades. The share of agriculture in total value added (37\% in 1960) and that in total employment $(66 \%)$ halved in two decades, while the share of industry in total value $(20 \%)$ doubled and that in employment (9\%) more than tripled. However, the share of services in economy remained stable while the share of this sector in total employment increased from $27 \%$ to $37 \% .^{13}$

Industrialization, which went hand in hand with export-led growth, altered the composition of exported and imported products. The exports of the primary goods in total exports decreased from $23 \%$ to $3 \%$ from 1967 to 1980 , while its share in total imports increased from $25 \%$ to $45 \%$ in the same period. While the exports of primary goods attenuated in the course of time, the imports share of the latter steadily decreased until the 1997 crisis and retook off again. The longterm trends, from 1967 to 2013, indicate that the share of consumption goods in exports has decreased from $31 \%$ to $18 \%$ while the share of equipment goods has increased from $3 \%$ to $28 \%$, and they constitute the most important export items. The trends also point to a long-run decline in the share of intermediate and equipment goods within the total imports. ${ }^{14}$

During the period 1960-70, the average annual growth rate of exports was $34.1 \%$, far outpacing that of the middle-income oil importing countries whose average annual growth rate of exports was $7.1 \%$. 1970s witnessed a similar pace with $23 \%$ compared to $4.3 \% .{ }^{15}$ The growth in exports was accompanied by a trade deficit that persisted until the 1997 Asian crisis. The share of the trade in total output was also subject to change in the course of time. International trade was almost negligible for South Korea in 1960, however, in 1980, the share of the exports in total value added was $10 \%$, and that of the imports was $16 \%$. The weight of international in the economy went far beyond these figures by continuation of the export-led growth. In 2011, the exports constituted the half of the GDP, while the imports to GDP ratio was $43 \%$. The increasing international trade went hand in hand with the increasing share of investment until the 1997 Asian crisis. While the investment share of GDP almost steadily increased and peaked up to $39 \%$ just before the crisis in 1996, it has been declining since then. As of 2011, investment only constitutes one quarter of the GDP of South Korea. Meanwhile the economy was confronted with a steadily declining consumption share, which was $77 \%$ in 1960 and became $51 \%$ in $2011 .{ }^{16}$ A decreasing labor income share also accompanied the decline in the consumption.

Hart-Landsberg ${ }^{17}$ explains the rapid export-led growth between the early 1960s and 1997 in South Korea by two international and two domestic factors. At international level, the Japanese

13 Hart-Landsberg, 1993, p.28-29.

14 CEPII (2014). CHELEM (Comptes Harmonisés sur les Echanges et L'Economie Mondiale, Harmonized international trade flows, balances of payments and world revenues), https://chelem.bvdep.com, (Date of Access: 28.04.2014)

15 Hart-Landsberg, 1993, p.31.

16 World Bank (2014). World Bank Development Indicators, http://databank.worldbank.org/data/download/archive/ WDI_excel_2014_04.zip, Date of Access (14.04.2014).

17 Hart-Landsberg, M. (2009).The Promise and Perils of Korean Reunification, Monthly Review, 60(11): 50-59. 
were ready to export their technology, components, and machinery to the chaebols ${ }^{18}$, and the U.S. was willing to politically and financially support the South Korean government. At domestic level, the economy was controlled by the State, which was ruled by the military, and the labor force was repressed. However, he asserts that the South Korean growth after the 1997 crisis owed to four factors: Government deficit spending, foreign direct investment, consumer spending, and exports.

South Korea, starting from a low-income agriculture economy, turned into an export base in a few decades. However, this growth pattern was accompanied by a long-run decline, except some periods, in the share of the labor in total value added. This decline became even more significant after the 1997 crisis and the last global economic and financial crisis has even accelerated this decline. In the next section, we present the evolution of labor income share in South Korea according to different sources.

\section{Labor Income Share in South Korea}

Measuring labor share in South Korea, as a member country of OECD, is a relatively easier task, compared to other economies in the East and Southeast Asia. ${ }^{19}$ We used two databases; those of the ILO and the OECD, for labor income share series and constructed a new one through retropolation.

ILO Global Wage Database ${ }^{20}$ provides two labor share series, an unadjusted, i.e. total compensation of employees as a share of GDP, and an adjusted, for the self-employed, for South Korea. The former series, available from 1995 to 2011, oscillate around 50\%, while the latter declines from $74 \%$ to $63 \%$ in the same time span. The series calculated by the OECD ${ }^{21}$ cover the period 1970-2011 and they have a similar trend with the adjusted ILO series during the period $1995-2011$.

The unadjusted series provided by the ILO underestimate the labor income share in South Korea while the OECD series seem to overestimate it. ${ }^{22}$ Since the adjusted ILO series cover only a short span of time, we opt for using these series for the period 1995-2011 along with the retropolated OECD series. Maintaining the former series, we depart from the level of its first available point, i.e. in 1995, and recalculate a new series using the growth rate of the OECD series for the period 1970-1995. Those new series, titled "ILO-OECD Reconstructed" are presented along with the other series from the ILO and the OECD in Figure 1.

18 Chaebols are Korean family-owned holding companies.

19 See, for example, Jetin and Kurt (2016), for a comparison with measurement and adjustment of labor income share in Thailand.

20 ILO (2014), Global Wage Database, www.ilo.org, (Date of Access: 29.05.2014)

21 OECD (2014), OECD.Stat, http://stats.oecd.org, (Date of Access: 27.05.2014)

22 As of 1970 , OECD series takes the value of $95 \%$ and $71 \%$ in 2011. 
Figure I: Labor income share (\% of GDP at factor cost) in South Korea (I970 - 20II)

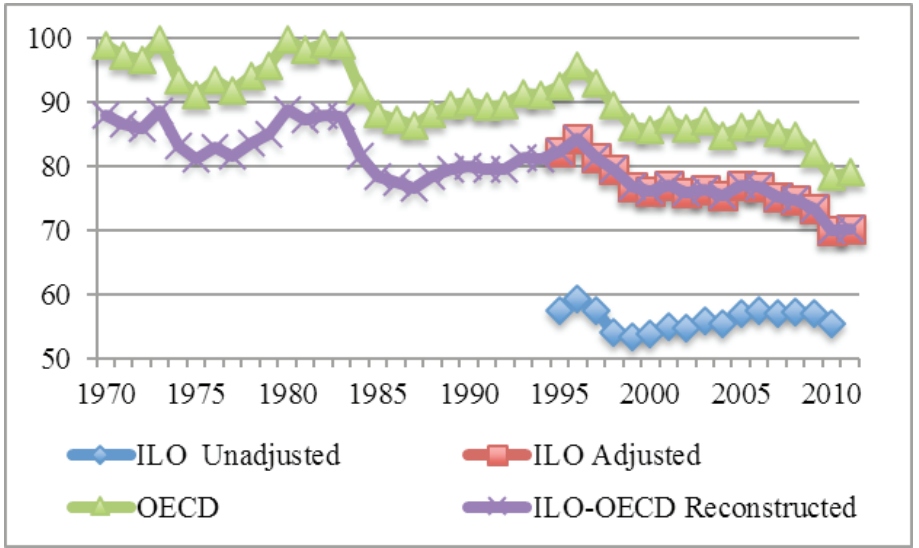

Source: ILO, Global Wage Database, 2014 and OECD, OECD.Stat, 2014

The reconstructed series, starting with $88 \%$ is in a steady trend of decline during the whole period except two sub periods. We observe two temporary periods of ascent in the late 1970s until early 1980s and another starting in late 1980s until the 1997 Asian crisis. However, the labor income share continues decreasing in the post-crises period. The decline is even more apparent when the share of labor income in GDP at market prices is considered. ${ }^{23}$ The decline is more than $20 \%$ in four decades. After the last economic and financial crisis of 2008-2009, a faster decline in the labor share is observed. As stated in the previous section, in parallel with the decline in the labor income share, the consumption share in GDP decreased and exports share, along with imports, in GDP increased from 1960s on. This, at the first sight, might be a sign of a long-run tradeoff between consumption/ labor income and exports. As for the investment we do not observe a stable pattern, though. In the next section we present our theoretical approach that addresses these issues.

\section{Theoretical Approach and Variables}

Wages, in general, are considered a cost factor in production within the neoclassical paradigm. However, post Keynesian framework provides a different explanation to its relation to demand/ output. While lower unit labor costs, hence wages, policies are praised for attaining higher export shares in world markets; wages as a determinant of domestic demand is pushed to background. Post Keynesian, in particular post Kaleckian models of income distribution and growth address these issues by taking both domestic and international markets into account. In this framework an increase in labor's share in total income might lead to a growth in output, which is the case of wage-led demand. Increased share of labor might result in a decrease in output, which is the case of profit-led demand regime.

23 We do not exhibit the evolution of the labor income share as a percentage of GDP in market prices due to space limitations. 
An important distinction to be made within the framework of the post Keynesian models of income distribution and growth is that among demand, accumulation and productivity regimes. Capital accumulation and productivity regimes might, as well, be wage or profit-led. In our framework, we focus on demand and its growth, while capital accumulation and technical progress are not treated. ${ }^{24}$ The analysis and its results are pertinent to short-run since there is no capital accumulation in the model.

It should be underlined that income distribution is not the unique, but an important factor that determines growth. Monetary and fiscal policies, exogenous shocks such as oil price shocks, shifts in real exchange rates etc. also have influences on aggregate demand. ${ }^{25}$ The aim of this analysis is rather to find the impact of variations in (exogenous) income distribution on demand (growth) in the short-term.

The model employed for the analysis of the demand regime in South Korea is by Jetin and Kurt ${ }^{26}$, which is a modified version of the model by Stockhammer, Onaran, and Ederer ${ }^{27}$, the latter being based on the theoretical model in the seminal work of Bhaduri and Marglin ${ }^{28}$. In the first two type of models, income distribution has separable effects on consumption $(C)$, investment $(I)$, exports $(\mathrm{X})$ and imports $(\mathrm{M})$ (or net exports $N X)$. The demand components are functions of income $(Y)$, labor (income) share $(L S)$, and some other control variables. The government sector is excluded from the model since the government expenditures depend only on income or they are exogenous. Then the aggregate demand can be written as:

$$
A D=C(Y, L S)+I(Y, L S)+N X(Y, P)(1)
$$

where $P$ is the domestic price level, which is a (indirect) function of $L S$. Differentiation of the equation (1) with respect to $L S$ and goods market equilibrium condition $\left(Y^{*}=A D\right)$ gives:

$$
\left(d Y^{*} / d L S=h_{2} /\left(1-h_{1}\right)(2)\right.
$$

where $h_{1}=\partial C / \partial Y+\partial I / \partial Y+\partial N X / \partial Y$ and $h_{2}=\partial C / \partial L S+\partial I / \partial L S+\partial N X / \partial L S$. For the stability of the model, the multiplier $1 /\left(1-h_{1}\right)$ should be positive. The sign of $h_{2}$, which is called private excess demand, determines the sign of the total derivative. The latter gives the change in demand due to a variation in income distribution at a fixed level of income. The sign of $h_{2}$ cannot be known in advance without an empirical investigation since the partial derivatives have different signs and the model does not give any information about their magnitudes. $\partial \mathrm{NX} / \partial \mathrm{Y}$ is equal to $\partial \mathrm{X} / \partial \mathrm{Y}-$ $\partial \mathrm{M} / \partial \mathrm{Y}$; however, since there is no effect of domestic income on the exports, the term reduces to

24 See Hein (2014) for an extensive theoretical and empirical literature review covering these models. Hein, E. (2014). Distribution and Growth After Keynes: A Post-Keynesian Guide, Cheltenham, Edward Elgar.

25 Lavoie, M., Stockhammer, E. (2013). "Wage-led Growth: Concept, Theories and Policies", Wage-led Growth: An equitable strategy for economic recovery, Editor: Marc Lavoie, Engelbert Stockhammer, New York, Palgrave Macmillan, 13-39, p. 23

26 Jetin and Kurt, 2016.

27 Stockhammer et al., 2009.

28 Bhaduri and Marglin, 1990. 
- $\partial \mathrm{M} / \partial \mathrm{Y}$. Eventually, $h_{1}$ becomes $\partial C / \partial Y+\partial I / \partial Y-\partial M / \partial Y$. If $d Y^{*} / d L S$ is positive then the demand regime is wage-led; otherwise it is profit-led.

The change in aggregate demand starts off by a change in income distribution. The multiplier mechanism will have an effect on consumption, investment, and imports. For a given level of Y, the total effect of income distribution on the equilibrium demand can also be written as:

$$
\left(d Y^{*} / Y\right) / d L S=h_{2} /\left(1-h_{1}\right)(3)
$$

which gives the percentage change in the demand due to a one percent increase in the LS, where

$$
h_{2}=\partial C / Y / \partial L S+\partial I / Y / \partial L S+\partial N X / Y / \partial L S .^{29}
$$

The demand regime might be different for domestic and open economies. The former is composed of consumption and investment, while the latter, in addition, includes exports and imports. If consumption is more sensitive to a change in labor income share than investment, then the economy is wage-led; otherwise it is profit-led. According to the post Keynesian approach, an increase in labor share promotes household consumption but investments decrease due to lower profit shares. Increasing labor share is supposed to stimulate the consumption of the workers more than that of the capitalists. ${ }^{30}$ If the domestic economy is wage-led, the total economy might or not be wage-led. If the domestic economy is profit-led, the total economy, as well, must be profit-led since the effect of the labor share on net exports is negative.

The model of Jetin and Kurt ${ }^{31}$ maintain the analytical framework of that of Stockhammer, Onaran and Ederer ${ }^{32}$ for the domestic economy and the imports function, but they integrate some elements of international price competition into the modeling of exports. As for the domestic economy, the consumption function is of the form $C=f(W, R)$, where $W$ is the labor income and $R$ is the capital income, including all non-labor income. The investment function is of the form $I=f(Y, R)$, which takes into account both the size of the economy and the profits. The exports function proposed by Stockhammer, Onaran and Ederer ${ }^{33}$ is of the form $X=f\left(Y_{f o r}, E\right.$, $P_{x} / P_{m}$ ), where $Y_{\text {for }}$ is the main foreign trade partners' weighted GDP, $E$ is the exchange rate and $P_{x} / P_{m}$ is the terms of trade, $P_{x}$ being the export prices and $P_{m}$ the import prices. The imports are modeled as $M=f\left(Y, E, P / P_{m}\right)$.

The exports function employed by Jetin and Kurt ${ }^{34}$ is different at two points. Firstly, it is a function of the relative export prices $P_{x}^{r e l}$, which is the ratio of $P_{x}$ to $P_{x}^{c o m p}$, the latter being the weighted export prices of the competitor countries. This assumption is more realistic since the

29 We use this version of the multiplier for our calculations.

30 At the margin, Kaldor's phrase "Capitalists earn what they spend, and workers spend what they earn" gives the gist of this assumption. Kaldor, N. (1955/56). Alternative Theories of Distribution, Review of Economic Studies, 23(2): 83-100.

31 Jetin and Kurt, 2016. See the table at p. 341 for the comparison of the two models.

32 Stockhammer et al., 2009.

33 Stockhammer et al., 2009.

34 Jetin and Kurt, 2016. 
importing countries compare export price of exporting countries, not their import prices. The export prices $P_{x}$ is a function of $P$ and $P_{x}^{c o m p}$ within a price maker/price taker setting. The impact of the import prices on the export prices is not put aside but captured through the domestic prices. $P$ is a function of $P_{m}$ and unit labor costs $(U L C)$. The other difference is that exports are a function of the total (weighted) imports of the world, but not of the GDP of the rest of the world. The import function is identical in both models. ${ }^{35}$ The detailed definitions of the variables and corresponding data series and sources are in the Appendix.

\section{Review of Empirical Literature}

The approaches to testing the post Kaleckian models of income distribution, in terms of theoretical modeling and econometric methodology, are quite diverse. The literature review is not exhaustive but it provides access to the remaining literature. As mentioned above, our model focuses on the demand regime and does not treat capital accumulation and productivity regimes. We limit the review to models without capital accumulation and technical progress, though we refer to models testing the demand and productivity regime in South Korea.

Two different econometric methodologies are used in the literature. The majority of the empirical work is based on single equation estimation of consumption (or savings), investment, exports and imports (or net exports) functions. However, theoretical framework and empirical equations are not identical. Consumption functions are almost estimated in the same manner and investment equations slightly differ. The main difference among models stems from the treatment of the international trade and the auxiliary price equations required for integration of unit labor costs, and exports and import prices into the models.

Bowles and Boyer ${ }^{36}$ are the first to apply single equation methodology to some developed countries. Storm and Naastepad ${ }^{37}$ examine the growth pattern regime of the East and Southeast Asian countries, including South Korea; however they integrate technological progress (productivity regime) into their model. Naastepad and Storm ${ }^{38}$ analyze eight member countries of the OECD and conclude that the demand is wage-led in France, Germany, Italy, the Netherlands, Spain, and the U.K.; profit-led in Japan and the U.S. Hein and Vogel ${ }^{39}$ examine Austria, France, Germany, the Netherlands, the UK, and the U.S. Stockhammer, Onaran, and

35 The exchange rate is not used in exports and imports functions but it is implicitly taken into account by internationally comparable price indices.

36 Bowles, S., Boyer,R. (1995). Wages, aggregate demand, and employment in an open economy: an empirical investigation", Macroeconomic Policy after the Conservative Era: Studies in Investment, Saving and Finance, Editor: G. A. Epstein, H. M Gintis, Cambridge (UK), Cambridge University Press, p. 143-71.

37 Storm, S., Naastepad, C. W. M. (2005). Strategic factors in economic development: East Asian industrialization 1950-2003, Development and Change, 36(6): 1059-94.

38 Naastepad, C. W. M., Storm, S. (2006/7). OECD demand regimes (1960-2000), Journal of Post-Keynesian Economics, 29(2): 213-48.

39 Hein, E., Vogel, L. (2008). Distribution and growth reconsidered: empirical results for six OECD countries, Cambridge Journal of Economics, 32(3): 479-511. 
Ederer ${ }^{40}$ apply the aforementioned model to the Euro area, considering it as a single country, and find that it is wage-led. Hartwig ${ }^{41}$ applies Naastepad and Storm's ${ }^{42}$ model treating both demand and productivity regimes, to the OECD countries, including South Korea, using panel data. He finds that the demand regime in the average OECD regime is wage-led. Molero-Simarro ${ }^{43}$ finds that the demand regime of China is profit-led. Onaran and Galanis ${ }^{44}$ conduct a comprehensive analysis of several countries, including South Korea, over the period 1960-2007. They use the theoretical model and methodology of Stockhammer, Onaran, and Ederer ${ }^{45}$ but they carry it one step further. They conduct empirical research on sixteen of the G20 countries to analyze the interactions among countries calculating global multipliers. Their model enables examination of the impact of a simultaneous change in the labor income share at a global level on individual countries. They conclude that the global economy is wage-led and in case of a worldwide race to the bottom in the labor share, the global GDP contracts. More recently, Onaran and Obst ${ }^{46}$ apply a similar model to the EU15 and find that a simultaneous decline in the labor income share has a significant negative effect on demand in the EU15.

The other type of models takes into account the interactions among the variables through use of Vector Autoregressive Models (VAR). These studies provide a system approach to estimation of some Kaleckian hypotheses. Gordon ${ }^{47},{ }^{48}$ employs such a model, along with single equation estimations, for the U.S. Stockhammer and Onaran ${ }^{49}$ apply a structural VAR model in their analysis of the U.S., the U.K. and France, where they test a set of hypotheses. Onaran and Stockhammer ${ }^{50}$ apply a similar model to South Korea and Turkey, and find some evidence for wage-led regimes. However, the models and their results are not directly comparable with

40 Stockhammer et al., 2009.

41 Hartwig, J. (2014). Testing the Bhaduri-Marglin model with OECD panel data, International Review of Applied Economics, 28(4): 419-35.

42 Naastepad and Storm, 2006/7.

43 Molero-Simarro, R. (2015). Functional distribution of income, aggregate demand, and economic growth in the Chinese economy, 1978-2007, International Review of Applied Economics, 29(5): 435-54.

44 Onaran, Ö., Galanis, G. (2014). Income Distribution and Growth: A Global Model, Environment and Planning A, 46(10): 2489-2513.

45 Stockhammer et al., 2009.

46 Onaran, O., Obst, T. (2016). Wage-led growth in the EU15 member-states: the effects of income distribution on growth, investment, trade balance and inflation, Cambridge Journal of Economics, 40(6): 1517-1551.

47 Gordon, D.M. (1995). Putting the horse (back) before the cart: disentangling the macro relationship between investment and saving, Macroeconomic Policy after the Conservative Era. Studies in Investment, Saving and Finance, Editor: G. A. Epstein, H. M Gintis, Cambridge (UK), Cambridge University Press, 57-108.

48 Gordon, D.M. (1995). Growth distribution and the rules of the game: social structuralist macro foundations for a democratic economic policy", Macroeconomic Policy after the Conservative Era. Studies in Investment, Saving and Finance, Editor: G. A. Epstein, H. M Gintis, Cambridge (UK), Cambridge University Press, 335-83.

49 Stockhammer, E., Onaran, O. (2004). Accumulation, Distribution and Employment: A Structural VAR Approach to a Kaleckian Macro-Model, Structural Change and Economic Dynamics, 15(4): 421-47.

50 Onaran, O., Stockhammer, E. (2005). Two Different Export-Oriented Growth Strategies: Accumulation and Distribution in Turkey and in South Korea, Emerging Markets Finance and Trade, 41(1): 65-89. 
those of the first type of analyses. The latter find that the total economy of South Korea is wageled. Barbosa-Filho and Taylor ${ }^{51}$ adopt a similar approach for the U.S. and find that the overall economy is profit-led.

\section{Estimation of Model Parameters and Results}

In this section we present the estimation procedure of the parameters of the equations of the model and our estimations based on this procedure, comparing them with the other findings in the literature and interpret the economic meaning of our results.

We first examined the stationarity properties of the series in logarithms using the Augmented Dickey-Fuller (ADF) test. The highest order of integration is found to be 1, i.e. I(1). When all the series in same equation were I(1) we tested for cointegration among them using the EngleGranger (EG) method. In case of no cointegration, we ran an ordinary least squares (OLS) in differences of variables. When all the variables in same equation were stationary we applied the OLS method in differences, as well, since we are interested in the short-run effects. In some estimations autoregressive terms are included using the Prais-Winsten (PW) method. Dummy variables are employed in order to control for outliers in some equations. In case variables in same equation were not of same order, we employed the Bounds test of Pesaran, Shin and Smith ${ }^{52}$. When cointegration tests gave no sign of cointegration or were inconclusive, OLS method in differences of the variables is employed. ${ }^{53}$

After applying the relevant estimation technique, we checked the robustness of the estimated equations by using the standard tests on residuals and coefficients. For the residuals, we report the Durbin Watson test statistic and the probability values for White's heteroscedasticity test, the autoregressive conditional heteroscedasticity (ARCH) test with one lag, and the Doornik-Hansen normality test. For the overall significance of the model and the parameters, probability values of the F-test, RESET test, and CUSUM tests are presented. In order to check for multicollinearity among the regressors, we report the VIF (variance inflation factor). ${ }^{54}$

\section{I. Consumption Equation}

Consumption and labor income $(W)$ series in logarithm are non-stationary but capital income $(R)$ is stationary. At the first step we conducted the Bounds tests for the consumption equation. While the Bounds F-test statistic shows signals of cointegration, this is not confirmed by the Bounds

51 Barbosa-Filho, N.H., Taylor, L. (2006). Distributive and demand cycles in the US economy-a structuralist Goodwin model, Metroeconomica, 57(3): 389-411.

52 Pesaran, M. H. et al. (2001). Bounds testing approaches to the analysis of level relationships, Journal of Applied Econometrics, 16(3): 289-326. Three outcomes are possible due to the nature of the test. The series might be cointegrated, stationary, or the test might not be conclusive.

53 The results of the ADF, EG and Bounds tests are not presented due to space limitations but they are available on request.

54 We report the highest VIF of the regressors of a given regression. Values greater than 10 point to multicollinearity. 
t-test statistic. There is either no cointegration, or no conclusion can be drawn. Therefore, we estimated the equation in differences of the series. The regression results are presented in Table 1.

We conducted two regressions for the consumption function. The first specification suffers from heteroscedasticity and the sum of the propensities to consume out of two income types is superior to unity. In order to overcome this problem, we employed a dummy variable controlling the sharp decline in consumption and income due to the 1997 crisis and used the Prais-Winston method since otherwise the errors were autocorrelated. ${ }^{55}$ The propensities obtained in the second estimation are more realistic. As expected, the propensity to consume out of wages $\left(e_{C W}\right)$ is higher than that out of profits $\left(e_{C R}\right)$. The high differential of 0.58 is an indication of wage-led demand, at least for the domestic economy. We use the results of this second specification in our calculations. Onaran and Galanis ${ }^{56}$ find $e_{C W} 0.85$ and $e_{C R} 0.07$, which gives a higher differential of consumption propensities, which is a stronger sign of having a more wage-led demand regime.

Table I: Consumption equation estimations (1970-20I I)

\begin{tabular}{|c|c|c|c|c|}
\hline \multicolumn{5}{|c|}{ Estimated equation: $\Delta \ln C=$ constant $+e_{C W} \Delta \ln W+e_{C R} \Delta \ln R$} \\
\hline Regressors & Coefficient & t-ratio & Coefficient & t-ratio \\
\hline Constant & -0.012 & -1.798 & 0.008 & 1.062 \\
\hline$\Delta \ln W$ & $0.962^{* \star *}$ & 11.440 & $0.71^{\star * \star}$ & 8.082 \\
\hline$\Delta \ln R$ & $0.162^{* * *}$ & 6.332 & $0.13^{* * *}$ & 5.927 \\
\hline$D_{1098}$ & & & $-0.105^{\star * *}$ & -5.229 \\
\hline$Q^{\mathrm{a}}$ & & & \multicolumn{2}{|l|}{0.248} \\
\hline \multicolumn{5}{|l|}{ Diagnostics } \\
\hline $\mathbf{R}^{2}$ & \multicolumn{2}{|l|}{0.783} & \multicolumn{2}{|l|}{0.868} \\
\hline Adjusted $\mathbf{R}^{2}$ & \multicolumn{2}{|l|}{0.771} & \multicolumn{2}{|l|}{0.857} \\
\hline DW statistic & \multicolumn{2}{|l|}{2.009} & \multicolumn{2}{|l|}{1.836} \\
\hline White's heteroscedasticity test ${ }^{\mathrm{b}}$ & \multicolumn{2}{|l|}{0.000} & \multicolumn{2}{|l|}{\begin{tabular}{|c|c|c|} 
\\
\end{tabular}} \\
\hline ARCH test $(1 \text { lag })^{b}$ & \multicolumn{2}{|l|}{0.139} & \multicolumn{2}{|l|}{0.417} \\
\hline Normality test ${ }^{\mathrm{b}}$ & \multicolumn{2}{|l|}{0.162} & \multicolumn{2}{|l|}{0.016} \\
\hline F-test ${ }^{b}$ & \multicolumn{2}{|l|}{0.000} & \multicolumn{2}{|l|}{0.000} \\
\hline RESET test (with squares) ${ }^{b}$ & \multicolumn{2}{|l|}{0.000} & \\
\hline CUSUM test $^{\mathrm{b}}$ & \multicolumn{2}{|l|}{0.756} & \multicolumn{2}{|l|}{\begin{tabular}{|c|c|c|} 
\\
\end{tabular}} \\
\hline Highest VIF & \multicolumn{2}{|l|}{1.144} & \multicolumn{2}{|l|}{1.772} \\
\hline
\end{tabular}

Source: Author's own calculations. ${ }^{* * *, * *}$ and ${ }^{*}$ represent 1,5 and $10 \%$ significance levels, respectively.

${ }^{a} \varrho$ is the autoregression parameter of the Prais-Winston method.

$\mathrm{b}$ Probability values of the corresponding tests

55 We carried out the estimations using the software GRETL. Heteroscedasticity, RESET, and CUSUM tests are not available when the PW method is used. However, while the residuals became homoscedastic, autocorrelation among the series was detected by adding the variable $D_{1998}$. We do not report the results of this intermediate estimation. Cottrell, A., Lucchetti, R. (2015). GRETL: Gnu regression, econometrics and time-series library, http://gretl. sourceforge.net.

56 Onaran and Galanis, 2014. 


\subsection{Investment Equation}

The unit root tests show that the investment $(I)$ and the capital income $(R)$ series in logarithm are stationary while output series $(Y)$ is non-stationary. The Bounds t-test shows no indication of cointegration among the series Consequently we estimated the equation in differences of the variables by using two specifications. The regression results are in Table 2.

The first regression without dummy variables ended up with a problem of heteroscedasticity. In order to prevent it we added dummy variables for the 1997 crisis; however, it did not turn out to be significant. The residuals showed that the outlier was the year 1978, and we added a dummy for this year, which became significant. The White test for the first regression shows that the residuals are homoscedastic; however, the Durbin-Watson statistic is at the limit of 1.60. In order to improve the estimation, we used the PW method in the second estimation. We opt for this specification in our calculations. The results show that profit share is not significant in both of the estimations. While the aggregate demand multiplier $\left(e_{I Y}\right)$ is 2.46 in the first estimation, it became 2.30 in the second one, which we employ in our calculations. Onaran and Galanis 57 include government investment as an explanatory variable in the estimation of their private investment function to control for crowding-in or crowding-out effects but this variable does not turn out to be significant. $e_{I Y}$ is found 2.51, in their estimation.

Table 2: Investment Equation Estimations (1970-20II)

\begin{tabular}{|c|c|c|c|c|}
\hline \multicolumn{5}{|c|}{ Estimated Equation: $\Delta \ln I=$ constant $+e_{\mathrm{IV}} \Delta \ln Y+e_{\mathrm{IR}} \Delta \ln R$} \\
\hline Regressors & Coefficient & t-ratio & Coefficient & t-ratio \\
\hline Constant & -0.078 & -5.691 & $-0,068^{\star * *}$ & -4.565 \\
\hline$\Delta \ln R$ & -0.051 & -0.971 & $-0,053$ & -1.087 \\
\hline$\Delta \ln Y$ & $2.46^{* * *}$ & 12.350 & $2.299^{* * *}$ & 11.770 \\
\hline$D_{1978}$ & $0.15^{\star * *}$ & 3.492 & $0.121^{\star * *}$ & 3.007 \\
\hline$Q^{\mathrm{a}}$ & & & \multicolumn{2}{|l|}{0.298} \\
\hline \multicolumn{5}{|l|}{ Diagnostics } \\
\hline $\mathbf{R}^{2}$ & \multicolumn{2}{|l|}{0.831} & \multicolumn{2}{|l|}{0.845} \\
\hline Adjusted $\mathrm{R}^{2}$ & \multicolumn{2}{|l|}{0.823} & \multicolumn{2}{|l|}{0.832} \\
\hline DW statistic & \multicolumn{2}{|l|}{1.602} & \multicolumn{2}{|l|}{1.861} \\
\hline White's heteroscedasticity test ${ }^{\mathrm{b}}$ & \multicolumn{2}{|l|}{0.604} & \\
\hline ARCH test $(1 \text { lag })^{b}$ & \multicolumn{2}{|l|}{0.408} & \multicolumn{2}{|l|}{0.781} \\
\hline Normality test $\mathrm{t}^{\mathrm{b}}$ & \multicolumn{2}{|l|}{0.116} & \multicolumn{2}{|l|}{0.183} \\
\hline F-test ${ }^{b}$ & \multicolumn{2}{|l|}{0.000} & \multicolumn{2}{|l|}{0.000} \\
\hline RESET test (with squares) ${ }^{b}$ & \multicolumn{2}{|l|}{0.837} & \multicolumn{2}{|l|}{ 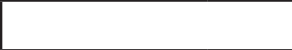 } \\
\hline CUSUM test $^{\mathrm{b}}$ & \multicolumn{2}{|l|}{0.816} & \multicolumn{2}{|l|}{ 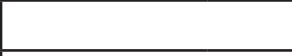 } \\
\hline Highest VIF & \multicolumn{2}{|l|}{1.098} & \multicolumn{2}{|l|}{1.098} \\
\hline
\end{tabular}

Source: Author's own calculations. ${ }^{* \cdots *}$, and ${ }^{*}$ represent 1,5 and $10 \%$ significance levels, respectively.

${ }^{a} \mathrm{Q}$ is the autoregression parameter of the Prais-Winston method.

${ }^{\mathrm{b}}$ Probability values of the corresponding tests

57 Onaran and Galanis, 2014. 


\subsection{Exports Equation}

We estimated the exports equation with two alternative measures of world demand, a weighted sum of exports $\left(M_{w 1}\right)$ and a simple sum $\left(M_{w 2}\right)$. Both series in natural logarithms are $\mathrm{I}(1)$, while exports $(X)$ and relative export prices $\left(P_{x}^{r e l}\right)$ series are stationary for South Korea. As we previously did for the consumption and investment equations, we applied the Bounds test to the exports equation. The test results show no sign of cointegration among exports, world demand and relative export prices series. We estimated the equation in differences of the variables as shown in Table 3.

We used two specifications for the two sets of estimations of the exports function with different world demand measures. The first regressions suffer from heteroscedasticity, which is due to the sharp rise and falls in the exports in 1970s. We observe a sudden growth in exports in 1973, at around 56\%, in sharp contrast to the contraction by $2 \%$ in the aftermath of the oil crisis. ${ }^{58}$ After a few years the South Korean economy recovered and in 1976 achieved a 40\% growth rate in the exports. In order to solve the problem of heteroscedasticity, we tried several combinations of dummy variables corresponding to those three years. We finally kept all the variables for the years 1973, 1974, and 1976 in the second regressions, in which they are all significant with the expected signs. We employed the PW method to eliminate the autocorrelation.

The results of the second specifications in both set of regressions show that an increase in the world demand, measured by weighted or simple sum of global imports, by $1 \%$ leads to between $0.31-0.38 \%$ increase in the exports of South Korea. Jetin and Kurt ${ }^{59}$ estimate this coefficient 0.30 for Thailand with both measures of the world demand. The magnitudes of the coefficients for the relative export prices differ considerably among the regressions with alternative measures of the world demand. The exports are more sensitive (-0.76) to export price variations if the measure of the world demand is $M_{w 1}$, while it is less in absolute value (-0.63) if $M_{w 2}$. We use the former in our calculations. Jetin and Kurt ${ }^{60}$ find this coefficient -0.67 and -0.66 for the two measures, respectively, in their analysis of Thailand.

\subsection{Imports Equation}

All the variables in the imports equation are I(1) according to the ADF unit root tests. However, we fail to reject the null hypothesis of no cointegration. Consequently, we estimated the equation in differences as in Table 4.

58 In 1973 the South Korean government had launched a program to establish some industries for both importsubstituting and export-generating purposes. The government applied subsidizations to capital in new heavy and chemical industries (Hart-Landsberg, 1993, p.38).

59 Jetin and Kurt, 2016.

60 Jetin and Kurt, 2016. 
Table 3: Exports Equation Estimations (1970-20II)

\begin{tabular}{|c|c|c|c|c|c|c|c|c|}
\hline \multicolumn{9}{|c|}{ Estimated Equation: $\Delta \ln X=$ constant $+\beta \Delta \ln M_{w i}+\kappa \Delta \ln P_{\mathrm{x}}^{\text {rel }}$} \\
\hline \multirow[b]{2}{*}{ Regressors } & \multicolumn{4}{|l|}{$\mathrm{j}=1$} & \multicolumn{4}{|l|}{$j=2$} \\
\hline & Coefficient & t-ratio & Coefficient & t-ratio & Coefficient & t-ratio & Coefficient & t-ratio \\
\hline Constant & $0.102^{* * *}$ & 5.444 & $0.089^{* * *}$ & 5.635 & $0.100^{* * *}$ & 5,180 & $0.091^{* * *}$ & 5.565 \\
\hline$\Delta \ln M_{\mathrm{wj}}$ & $0.303^{* * *}$ & 2.189 & $0.382^{* * *}$ & 3.801 & $0.291^{* *}$ & 2,212 & $0.312^{* * *}$ & 2.945 \\
\hline$\Delta \ln P_{\mathrm{x}}^{\text {rel }}$ & -0.527 & -1.331 & $-0.757^{\star *}$ & -2.683 & -0.405 & -1.052 & $-0.630^{* *}$ & -2.166 \\
\hline$D_{1973}$ & & & $0.260^{* * *}$ & 4.208 & & & $0.225^{\star * *}$ & 3.275 \\
\hline$D_{1974}$ & & & $-0.241^{* * *}$ & -3.482 & & & $-0.216^{* * *}$ & -2.980 \\
\hline$D_{1976}$ & & & $0.209^{* * *}$ & 3.090 & & & $0.242^{* * *}$ & 3.429 \\
\hline$\varrho^{\mathrm{a}}$ & & & 0.288 & & & & 0.240 & \\
\hline \multicolumn{9}{|l|}{ Diagnostics } \\
\hline $\mathbf{R}^{2}$ & \multicolumn{2}{|l|}{0.125} & \multicolumn{2}{|l|}{0.653} & \multicolumn{2}{|l|}{0.127} & \multicolumn{2}{|l|}{0.611} \\
\hline Adjusted $R^{2}$ & \multicolumn{2}{|l|}{0.079} & \multicolumn{2}{|l|}{0.603} & \multicolumn{2}{|l|}{0.081} & \multicolumn{2}{|l|}{0.555} \\
\hline DW statistic & \multicolumn{2}{|l|}{1.859} & \multicolumn{2}{|l|}{1.845} & \multicolumn{2}{|l|}{1.797} & \multicolumn{2}{|l|}{1.887} \\
\hline $\begin{array}{l}\text { White's } \\
\text { heteroscedasticity } \\
\text { test }^{\mathrm{b}}\end{array}$ & \multicolumn{2}{|l|}{0.120} & & & \multicolumn{2}{|l|}{0.000} & & \\
\hline ARCH test $(1 \mathrm{lag})^{\mathrm{b}}$ & \multicolumn{2}{|l|}{0.038} & \multicolumn{2}{|l|}{0.067} & \multicolumn{2}{|l|}{0.079} & \multicolumn{2}{|l|}{0.218} \\
\hline Normality test ${ }^{b}$ & \multicolumn{2}{|l|}{0.006} & \multicolumn{2}{|l|}{0.720} & \multicolumn{2}{|l|}{0.027} & \multicolumn{2}{|l|}{0.507} \\
\hline F-test ${ }^{b}$ & \multicolumn{2}{|l|}{0.079} & \multicolumn{2}{|l|}{0.000} & \multicolumn{2}{|l|}{0.076} & \multicolumn{2}{|l|}{0.000} \\
\hline $\begin{array}{l}\text { RESET test } \\
\text { (with squares) }^{b}\end{array}$ & \multicolumn{2}{|l|}{0.308} & & & \multicolumn{2}{|l|}{0.816} & & \\
\hline CUSUM test $^{\mathrm{b}}$ & \multicolumn{2}{|l|}{0.000} & & & 0.001 & & & \\
\hline Highest VIF & 1.071 & & 1.324 & & 1.014 & & 1.382 & \\
\hline
\end{tabular}

Source: Author's own calculations. ${ }^{, \ldots *, * * *}$ and ${ }^{*}$ represent 1,5 and $10 \%$ significance levels, respectively.

${ }^{a} \varrho$ is the autoregression parameter of the Prais-Winston method.

${ }^{b}$ Probability values of the corresponding tests

Estimation results show that an increase in the domestic demand by $1 \%$ leads to a $2.27 \%$ rise in the imports. The coefficient estimated by Onaran and Galanis ${ }^{61}$ is of exactly same magnitude, however in our estimation the domestic to import prices ratio $\left(P / P_{m}\right)$ is not significant, while they find the corresponding coefficient 0.25 , which is significant at $10 \%$. Our result points out that imported goods are not substitutable with the domestic ones.

61 Onaran and Galanis, 2014. 
Table 4: Imports Equation Estimation (I970-20II)

\begin{tabular}{|c|c|c|}
\hline \multicolumn{3}{|c|}{ Estimated Equation: $\Delta \ln M=$ constant $+e_{\mathrm{MV}} \Delta \ln Y+\gamma \Delta \ln P / P_{\mathrm{m}}$} \\
\hline Regressors & Coefficient & t-ratio \\
\hline Constant & $-0.040^{*}$ & $-1,932$ \\
\hline$\Delta \ln Y$ & $2.266^{* * *}$ & 7,286 \\
\hline$\Delta \ln P / P$ & 0.124 & 0,965 \\
\hline \multicolumn{3}{|l|}{ Diagnostics } \\
\hline $\mathbf{R}^{2}$ & 0.733 & \\
\hline Adjusted $\mathrm{R}^{2}$ & 0.719 & \\
\hline DW statistic & 1.665 & \\
\hline White's heteroscedasticity test ${ }^{\mathrm{a}}$ & 0.800 & \\
\hline ARCH test $(1 \mathrm{lag})^{\mathrm{a}}$ & 0.507 & \\
\hline Normality test ${ }^{\mathrm{a}}$ & 0.224 & \\
\hline F-test ${ }^{\mathrm{a}}$ & 0.000 & \\
\hline RESET test (with squares) ${ }^{a}$ & 0.896 & \\
\hline CUSUM test $^{\mathrm{a}}$ & 0.355 & \\
\hline Highest VIF & 1.668 & \\
\hline
\end{tabular}

The ADF unit root tests point to stationarity of the variables in the domestic prices equation. We estimated the equation via OLS in differences of the variables, instead of their levels, since we are interested in the short-term effects. The regression results are presented in Table 5.

We estimated an alternative regression with a dummy variable controlling for the year 1974, when South Korea witnessed an unexpectedly high inflation rate due to the oil crisis. However, adding this variable changed neither the qualitative results nor the estimated magnitude of the effect of unit labor costs on domestic prices. Both specifications indicate that a $1 \%$ increase in the unit labor costs lead to a $0.94 \%$ increase in the domestic prices. Onaran and Galanis ${ }^{62}$ find a much lower coefficient of 0.74 . The import prices have no effect on the domestic prices in our estimations. The latter find the corresponding coefficient 0.07 at $10 \%$ level of significance and the one period lagged coefficient 0.10 at $5 \%$ level of significance.

Table 5: Domestic Prices Equation Estimations (1970-20II)

\begin{tabular}{|c|c|c|c|c|}
\hline \multicolumn{5}{|c|}{ Estimated Equation: $\Delta \ln P=$ constant $+\eta \Delta \ln U L C+\mu \Delta \ln P$} \\
\hline Regressors & Coefficient & t-ratio & Coefficient & t-ratio \\
\hline Constant & $0.009^{*}$ & 2.002 & $0.009^{* *}$ & 2,383 \\
\hline$\Delta \ln U L C$ & $0.936^{* * *}$ & 21.340 & $0.935^{\star * *}$ & 24.040 \\
\hline$\Delta \ln P_{m}$ & 0.023 & 0.309 & -0.036 & -0.524 \\
\hline$D_{1974}$ & & & $0.077^{\star * *}$ & 3.362 \\
\hline \multicolumn{5}{|l|}{ Diagnostics } \\
\hline $\mathbf{R}^{2}$ & 0.952 & & 0.963 & \\
\hline Adjusted $\mathrm{R}^{2}$ & 0.949 & & 0.960 & \\
\hline DW statistic & 2.119 & & 2.187 & \\
\hline
\end{tabular}

\section{Onaran and Galanis, 2014.}




\begin{tabular}{|l|l|l|}
\hline White's heteroscedasticity test $^{\mathrm{a}}$ & 0.314 & 0.954 \\
\hline ARCH test $\left(\mathbf{l}\right.$ lag) $^{\mathrm{a}}$ & 0.050 & 0.070 \\
\hline Normality test $^{\mathrm{a}}$ & 0.054 & 0.434 \\
\hline F-test $^{\mathrm{a}}$ & 0.000 & 0.000 \\
\hline RESET test (with squares) $^{\mathrm{a}}$ & 0.436 & 0.143 \\
\hline CUSUM test $^{\mathrm{a}}$ & 0.186 & 0.854 \\
\hline Highest VIF & 1.623 & 1.737 \\
\hline
\end{tabular}

Source: Author's own calculations.

${ }^{a}$ Probability values of the corresponding tests

\subsection{Export Prices Equation}

All the variables in the export prices equation are stationary according to the unit root tests. Following the same approach in the previous subsection, we estimated an OLS equation in differences of the variables. The results of the estimation are presented in Table 6 .

The regressions show that both domestic prices and export prices of the competitors are significant in determining the export prices of South Korea. An increase in the domestic prices by $1 \%$ leads to a $0.22 \%$ rise in the export prices. The effect of the competitors' prices on export prices is 0.65 , which is in line with the price taker assumption for South Korea. Jetin and Kurt ${ }^{63}$ find these coefficients 0.31 and 0.41 , respectively, for Thailand.

Table 6: Export Prices Equation Estimation (1970-20II)

\begin{tabular}{|c|c|c|}
\hline \multicolumn{3}{|c|}{ Estimated Equation: $\Delta \ln P_{\mathrm{x}}=$ constant $+\lambda \Delta \ln P+\tau \Delta \ln P_{\mathrm{x}}^{\text {comp }}$} \\
\hline Regressors & Coefficient & t-ratio \\
\hline Constant & 0.002 & 0.304 \\
\hline$\Delta \ln P$ & $0.216^{* * *}$ & 4.101 \\
\hline$\Delta \ln P_{\mathrm{x}}^{\text {comp }}$ & $0.649^{* * *}$ & 6.687 \\
\hline \multicolumn{3}{|l|}{ Diagnostics } \\
\hline $\mathbf{R}^{2}$ & 0.752 & \\
\hline Adjusted $\mathbf{R}^{2}$ & 0.739 & \\
\hline DW statistic & 2.356 & \\
\hline White's heteroscedasticity test $\mathrm{t}^{\mathrm{a}}$ & 0.976 & \\
\hline ARCH test $(1 \mathrm{lag})^{\text {a }}$ & 0.651 & \\
\hline Normality test $^{\mathrm{a}}$ & 0.002 & \\
\hline F-test ${ }^{\mathrm{a}}$ & 0.000 & \\
\hline RESET test (with squares) ${ }^{\text {a }}$ & 0.217 & \\
\hline CUSUM test $^{\mathrm{a}}$ & 0.464 & \\
\hline Highest VIF & 1.306 & \\
\hline
\end{tabular}

63 Jetin and Kurt, 2016. 


\subsection{Calculation of the Effect of Income Distribution on Growth and Evaluation of the Econometric Findings}

The overall effect on an increase of the labor income share on economic growth is by the multiplier in the equation (3). The sign of the private excess demand $\left(h_{2}\right)$ characterizes the demand growth regime and $h_{1}$ determines its magnitude. We adopt the approach of Jetin and Kurt ${ }^{64}$ for our calculations since the model, hence the multipliers, are identical.

The first element of the $h_{1}$ is the marginal effect $\partial C / \partial Y$, which is equal to the multiplication of $\mathrm{e}_{\mathrm{CY}}$, the elasticity of $C$ with respect to $Y$, and the sample average of the ratio of $C$ to $Y . e_{C Y}$ cannot directly be retrieved from the regressions. Stockhammer, Onaran and Ederer ${ }^{65} \operatorname{sum} e_{C W}$ and $e_{C R}$ to estimate $e_{C Y}$, while Onaran and Galanis ${ }^{66}$ weight these propensities as $e_{C R}(R / Y)+e_{C W}(W / Y)$, where $R / Y$ and $W / Y$ are sample averages of these ratios. Since the weighted sum, which underestimates the income elasticity, is always lower than $e_{C W}$, we adopt the former approach. The second and the third elements of the $h_{1}$ are straightforward. $\partial I / \partial Y$ and $\partial M / \partial Y$ are equal to $e_{I Y} I / Y$ and $e_{M Y} M / Y$, respectively. As for the calculation of $h_{2}$, the first term $\partial C / Y / \partial L S$ is equal to $e_{C W} C / W-e_{C R} C / R$, where $\mathrm{C} / \mathrm{W}$ and $\mathrm{C} / \mathrm{R}$ are sample averages of these ratios. The second term $\partial I / Y / \partial L S$ is equal to $e_{I R}(I / R)(Y / Y)$, where $Y_{f}$ is the GDP at factor costs. The third term $\partial X / Y / \partial L S$ is calculated by the formula $[\kappa \lambda \eta /(1-\eta)](X / Y) / L S$. In the same manner, $\partial M / Y / \partial L S$ is calculated as $[\gamma \eta /(1-\eta)](M / Y) /$ $L S .{ }^{67}$ The effect of a $1 \%$ increase in the labor income share on the GDP components for a given level of output, the private excess demand, and the total demand are displayed in Table 7.

Table 7: Total effect of a $1 \%$ increase in the labor income share on the South Korean economy

$(1970-2011)$

\begin{tabular}{|c|c|}
\hline & \% Change \\
\hline Consumption $(\partial C / Y / \partial L S)$ & 0.117 \\
\hline Investment $(\partial I / Y / \partial L S)$ & 0.000 \\
\hline Domestic Economy & 0.117 \\
\hline Exports $(\partial X / Y / \partial L S)$ & -0.605 \\
\hline Imports $(\partial M / Y / \partial L S)$ & 0.000 \\
\hline Net Exports & -0.605 \\
\hline Private excess demand $\left(\boldsymbol{h}_{\boldsymbol{2}}{ }^{\mathbf{a}}\right)$ & -0.488 \\
\hline Total effect $\left(\boldsymbol{h}_{\mathbf{2}} /\left(\mathbf{1}-\boldsymbol{h}_{\perp}{ }^{\mathbf{b}}\right)\right)$ & -1.240 \\
\hline
\end{tabular}

Source: Author's own calculations.

${ }^{\mathbf{a}} h_{2}=\partial C / Y / \partial L S+\partial I / Y / \partial L S+\partial N X / Y / \partial L S$.

${ }^{b} h_{1}=\partial C / \partial Y+\partial I / \partial Y+\partial N X / \partial Y$. $h_{1}$ is found to be 0.61 .

The findings show that the aggregate South Korean demand is profit-led, while the domestic demand is wage-led. The variations in the labor share do not have short-term impact on the

64 Jetin and Kurt, 2016.

65 Stockhammer et al., 2009.

66 Onaran and Galanis, 2014.

67 See the appendix in Jetin and Kurt (2016) for derivation of the multipliers. 
investment and imports. The trade-off between the effects of an increase in the labor income share is between those on the consumption and the exports. Redistribution of income in favor of labor in the short term has no negative impact on the investment but it might promote consumption. A $1 \%$ increase in labor income share leads to a $0.12 \%$ increase in the consumption at a given level of GDP. However, while the imports are not influenced by such a policy, the exports are expected to decrease by $0.61 \%$, due to increasing unit labor costs. In sum, we find that a $1 \%$ increase in the South Korean labor income share leads to a $1.24 \%$ of contraction of the economy.

In the last section, we provide a further discussion on these results and draw policy conclusions from our findings along with a general assessment of our analysis.

\subsection{General Assessment, Policy Implications and Conclusion}

This article examined the viability of pro-labor policies in South Korea within the framework of a post Keynesian/post Kaleckian model. Our analysis shows that, with other conditions remaining the same, a one percent increase in the labor share would lead to a short-term decrease in GDP of more than one percent since the demand regime in South Korea is profit-led. An increase in the labor share has a significant negative effect on the exports (and net exports) that cannot balanced by the moderate positive counter effect on the consumption. The results in the previous study by Onaran and Galanis ${ }^{68}$, which is in general sense comparable with ours in terms of methodology, are partially in contradiction with our findings. While both studies show that income distribution has no impact on the investment (and imports at 5\%), they find that the overall economy as wells as the domestic one are wage-led: A $1 \%$ increase in labor income share results in a $0.12 \%$ growth in the South Korean GDP in their study. An increasing labor income share's effect on consumption more than offsets its effect exports in their study, while in our study the exports effect is quite strong. The differences of the findings are partially due to the treatment of the international trade but the use of different time series might also have played a role.

The model presented above brings along some shortcomings regarding some assumptions and operationalization of the equations. Besides, some results of the econometric investigation require further explanation. First, the exogenous income distribution assumption is questionable since production and distribution simultaneously take place they have feedback effects on each other. While it is plausible to consider the income distribution as an outcome of power relations, or more precisely class struggle between workers and capitalists, rather than marginal productivities of labor and capital; using instrumental variables would give more reliable results in terms of econometrics. However, finding appropriate instruments with sufficient number of observations is not an easy task. Second, the model does not take into account financialization, especially issues concerning household debts and rentier class. These elements are especially important for determination of consumption and investment. Integration of the rentier class, who receive 
dividends and interest payments, in the model would be more complete for consumption and investment functions, as in the study by Onaran, Stockhammer and Grafl ${ }^{69}$. Future research taking these aspects might give different results.

Another shortcoming, in relation with the first one, is that the consumption equation that we used might be flawed due to econometric reasons. The reason behind employing a consumption equation, as a function of wages and profits, is to estimate the corresponding consumption propensities out of these two income types. Since national accounts do not provide data on decomposition of consumption, such estimation becomes compulsory. The econometric problem that could arise is the collinearity of wages and profits. However, although levels of wages and profits are likely to be collinear, this is not necessarily the case for their growth rates, which are in logarithmic differences in our case. The estimations indicate that there is no long-run relationship between consumption, wages, and profits series for all the countries under examination. Therefore, the consumption equations are estimated in first differences of logarithms of these variables. VIFs also show no indication of collinearity among them.

The unsubstitutability of the domestic and imported goods, implied by the results of the estimated imports equation, deserves a more in-depth study. Besides, import prices do not have an impact on the domestic prices. These might be due to using aggregate quantities and prices in the analysis putting aside sectoral composition of those. An analysis, for example, by decomposing the imports and eliminating primary goods might give different results.

Jetin and Kurt ${ }^{70}$ underline that the profit-led character reflects the structure of a given economy and should be considered as a historical resume of the coevolution of the labor share and the output. Within the given structure of the South Korean economy, pro-labor growth policy is far from applicable in short-run. Nevertheless, regional wage coordination might change the game. Further research taking into account the multilateral trade among the countries in the region might give more information on the applicability of such cooperation. It should be noted that a common political agenda among countries is the prior condition to be filled for such cooperation. Lack of such a political agenda in the European Union, which is an economic and monetary union, gives an idea about the difficulty of such a task in East and Southeast Asia. Further research on the region that takes into account the interdependencies within a multi-demand framework, as in the study of Onaran and Galanis, ${ }^{71}$ and Onaran and Obst ${ }^{72}$, is likely to give more information about viability of such cooperation in the region, while political constraints still hold.

69 Onaran, O. et al. (2011). Financialisation, Income Distribution and Aggregate Demand in the USA. Cambridge Journal of Economics, 35(4): 637-661.

70 Jetin and Kurt, 2016.

71 Onaran and Galanis, 2014.

72 Onaran and Obst, 2016. 


\section{References}

BARBOSA-FILHO, N.H., Taylor, L. (2006). Distributive and demand cycles in the US economy-a structuralist Goodwin model, Metroeconomica, 57(3): 389-411.

BHADURI, A. and Marglin, S. (1990). Unemployment and the real wage: the economic basis for contesting political ideologies, Cambridge Journal of Economics, 14(4): 375-93.

BOWLES, S., Boyer,R. (1995). Wages, aggregate demand, and employment in an open economy: an empirical investigation", Macroeconomic Policy after the Conservative Era: Studies in Investment, Saving and Finance, Editor: G. A. Epstein, H. M Gintis, Cambridge (UK), Cambridge University Press, p. 143-71.

CEPII (2014). CHELEM (Comptes Harmonisés sur les Echanges et L'Economie Mondiale, Harmonized international trade flows, balances of payments and world revenues), https://chelem.bvdep.com, (Date of Access: 28.04.2014)

COTTRELL, A., Lucchetti, R. (2015). GRETL: Gnu regression, econometrics and time-series library, http:// gretl.sourceforge.net.

FEENSTRA, R. C., Inklaar, R., Timmer, M.P. (2013). The Next Generation of the Penn World Table, www. ggdc.net/pwt, (Date of Access: 17.09.2013)

FOSTER, J.B., Yates, M.D. (2014). Piketty and the Crisis of Neoclassical Economics, Monthly Review, 66(6): 1-24.

GORDON, D.M. (1995a). Putting the horse (back) before the cart: disentangling the macro relationship between investment and saving, Macroeconomic Policy after the Conservative Era. Studies in Investment, Saving and Finance, Editor: G. A. Epstein, H. M Gintis, Cambridge (UK), Cambridge University Press, 57-108.

GORDON, D.M. (1995b). Growth distribution and the rules of the game: social structuralist macro foundations for a democratic economic policy, Macroeconomic Policy after the Conservative Era. Studies in Investment, Saving and Finance, Editor: G. A. Epstein, H. M Gintis, Cambridge (UK), Cambridge University Press, 335-83.

HART-LANDSBERG, M. (1993). The rush to development: Economic change and political struggle in South Korea, New York, Monthly Review, p.26-27.

HART-LANDSBERG, M. (2009).The Promise and Perils of Korean Reunification, Monthly Review, 60(11): $50-59$.

HARTWIG, J. (2014). Testing the Bhaduri-Marglin model with OECD panel data, International Review of Applied Economics, 28(4): 419-35.

HEIN, E. (2014). Distribution and Growth After Keynes: A Post-Keynesian Guide, Cheltenham, Edward Elgar.

HEIN, E., Vogel, L. (2008). Distribution and growth reconsidered: empirical results for six OECD countries, Cambridge Journal of Economics, 32(3): 479-511.

ILO (2014), Global Wage Database, www.ilo.org, (Date of Access: 29.05.2014)

JETIN, B., Kurt, O.E. (2016). Functional income distribution and growth in Thailand: A post Keynesian econometric analysis, Journal of Post Keynesian Economics, 39(3): 334-60.

KALDOR, N. (1955/56). Alternative Theories of Distribution, Review of Economic Studies, 23(2): 83-100.

LAVOIE, M., Stockhammer, E. (2013). "Wage-led Growth: Concept, Theories and Policies", Wage-led Growth: An equitable strategy for economic recovery, Editor: Marc Lavoie, Engelbert Stockhammer, New York, Palgrave Macmillan, 13-39.

MOLERO-SIMARRO, R. (2015). Functional distribution of income, aggregate demand, and economic growth in the Chinese economy, 1978-2007, International Review of Applied Economics, 29(5): 435-54. 
NAASTEPAD, C. W. M., Storm, S. (2006/7). OECD demand regimes (1960-2000), Journal of Post-Keynesian Economics, 29(2): 213-48.

OECD (2014), OECD.Stat, http://stats.oecd.org, (Date of Access: 27.05.2014)

ONARAN, O., Galanis, G. (2014). Income Distribution and Growth: A Global Model, Environment and Planning A, 46(10): 2489-2513.

ONARAN, O., Obst, T. (2016). Wage-led growth in the EU15 member-states: the effects of income distribution on growth, investment, trade balance and inflation, Cambridge Journal of Economics, 40(6): 1517-1551.

ONARAN, O., Stockhammer, E. (2005). Two Different Export-Oriented Growth Strategies: Accumulation and Distribution in Turkey and in South Korea, Emerging Markets Finance and Trade, 41(1): 65-89.

ONARAN, O., Stockhammer, E., Grafl, L. (2011). Financialisation, Income Distribution and Aggregate Demand in the USA. Cambridge Journal of Economics, 35(4): 637-661.

PESARAN, M. H., Shin, Y., Smith, R.J. (2001). Bounds testing approaches to the analysis of level relationships, Journal of Applied Econometrics, 16(3): 289-326.

PIKETTY, T. (2014). Capital in the $21^{\text {st }}$ Century, Cambridge (US), Harvard University Press.

STOCKHAMMER, E., Onaran, O. (2004). Accumulation, Distribution and Employment: A Structural VAR Approach to a Kaleckian Macro-Model, Structural Change and Economic Dynamics, 15(4): 421-47.

STOCKHAMMER, E., Onaran, O., Ederer, S. (2009). Functional Income Distribution and Aggregate Demand in the Euro-area, Cambridge Journal of Economics, 33(1): 139-59.

STORM, S., Naastepad, C. W. M. (2005). Strategic factors in economic development: East Asian industrialization 1950-2003, Development and Change, 36(6): 1059-94.

WORLD BANK (2014). World Bank Development Indicators, http://databank.worldbank.org/data/ download/archive/WDI_excel_2014_04.zip, Date of Access (14.04.2014).

WORLD BANK (2017). World Bank Development Indicators, http://databank.worldbank.org/data/ download/WDI_excel.zip, (Date of Access: 01.03.2017)

\section{Appendix of variables and data sources}

All data used in the article are annual over the 1970-2011 period.

$C, I, X, M, Y$ : In constant 2005 dollars and retrieved from the WDI database of the World Bank.

$W, R$ : Adjusted sum of labor and capital incomes are calculated by multiplying the adjusted labor share by the GDP at factor costs in constant dollars. The latter is retrieved from the WDI database.

$M_{\text {wj }}$ : We used two alternatives for the world demand. The first one, denoted as $M_{w 1}=\sum_{i}^{N} \alpha_{i} M_{i}$, where $\alpha_{i}$ is the share of exports of South Korea towards a country $i$, i.e. $\alpha_{i}=\frac{x_{i}}{\sum_{i}^{N} X_{i}}$, and $M_{i}$ is the total imports of a country $i$. Alternatively, a simple sum of the imports of the rest of the world, denoted as $M_{w 2}=\sum_{i}^{N} M_{i}$, is used in the estimations. Trade data, including bilateral trade, are retrieved from the CHELEM database of the CEPII.

$P_{\mathrm{x}}, P_{\mathrm{x}}^{\text {comp }}, P_{\mathrm{x}}^{\text {rel }}$ and $P_{\mathrm{m}}$ : Normalized export and import price indices of South Korea and its competitors are retrieved from the Penn World Tables (PWT) 8.0 database. $P_{\mathrm{x}}^{\text {comp }}$ is the weighted price index of the trade partners of South Korea, where the weights are the shares of exports of 
the country to other countries in its total exports. $P_{\mathrm{x}}^{\text {rel }}$ is the ratio of $P_{\mathrm{x}}$ to $P_{\mathrm{x}}$ comp. Weights are calculated using the bilateral trade data from the CHELEM database.

$P$ : The price deflator used in the estimations is not the one calculated in local currency but it is converted into constant 2005 dollars. It is equivalent to $P \times \frac{\mathrm{ppp}_{\operatorname{mos}}}{\bar{E}}$ and it is normalized such that its value of 2005 is equal to 1 . This deflator is then used to calculate the unit labor costs. $P, P P P_{2005}$ and $E$ are retrieved from the Penn World Tables prepared by Feenstra et al. ${ }^{73}$

ULC: It is the ratio of the nominal compensation of workers to real output, i.e. real GDP at market prices. We obtain the real unit labor cost $(R U L C)$ if the labor compensation is also in real terms. The RULC and the $L S$ are slightly different. While the former is the ratio of the real labor compensation to real GDP at market prices $(Y)$, the latter is the share of the (real) labor compensation in (real) GDP at factor costs $\left(Y_{\mathrm{f}}\right)$.

73 Feenstra, R. C. et al. (2013). The Next Generation of the Penn World Table, www.ggdc.net/pwt, (Date of Access: 17.09.2013) 
